\title{
Emotions and Cognitions \\ Fourteenth-Century Discussions on the Passions of the Soul
}

DOMINIK PERLER

\begin{abstract}
Medieval philosophers clearly recognized that emotions are not simply "raw feelings" but complex mental states that include cognitive components. They analyzed these components both on the sensory and on the intellectual level, paying particular attention to the different types of cognition that are involved. This paper focuses on William Ockham and Adam Wodeham, two fourteenth-centuries authors who presented a detailed account of "sensory passions" and "volitional passions". It intends to show that these two philosophers provided both a structural and a functional analysis of emotions, i.e., they explained the various elements constituting emotions and delineated the causal relations between these elements. Ockham as well as Wodeham emphasized that "sensory passions" are not only based upon cognitions but include a cognitive component and are therefore intentional. In addition, they pointed out that "volitional passions" are based upon a conceptualization and an evaluation of given objects. This cognitivist approach to emotions enabled them to explain the complex phenomenon of emotional conflict, a phenomenon that has its origin in the co-presence of various emotions that involve conflicting evaluations.
\end{abstract}

\section{$I$}

Suppose that, during your childhood, you had a best friend who was very close, with whom you shared not only most of your time, but also most of your secrets. The two of you were inseparable at school and went through all the stormy stages of adolescence together. But then, one day, your friend suddenly disappeared without any explanation. You heard rumors that she had gone to Australia, but you received no message from her - no phone call, no postcard, nothing. It took you years to come to terms with this strange behavior. Yet one morning, when you were about to leave your apartment, all of a sudden she was standing at your door, smiling at you as if nothing had happened. How would you react? You 
would be in a complex emotional state, I assume, and you would go through various stages. First, you might feel sheer pleasure at seeing her, a pleasure that would immediately trigger bodily actions like running toward her and embracing her. But then you might also feel anger. Why did she leave so abruptly? And why did she show up after so many years without warning you? Finally, you might also feel a bit guilty. After all, you could have done something to learn about her whereabouts. You neglected to keep in touch as much as she did.

It is quite easy to imagine such a situation and to give a detailed description of the complex emotional state a person is likely to be confronted with. However, it is far from easy to provide a philosophical analysis of this state. In such an analysis, we need to do at least two things. First, we ought to give a structural explanation of the emotional state, i.e., we need to indicate what kind of components or elements are to be taken into account and how these elements are interrelated. Thus, it is necessary to delineate what we need to consider when we describe a person as feeling pleasure, anger, and guilt. Does such a person have mere feelings, comparable to sensations like feeling hungry and thirsty, or does she have mental states with a cognitive content? And how can we characterize this content? Second, it is also necessary to provide a functional explanation of the complex emotional state, spelling out what causes the various components and what they cause in turn. Should we say, for instance, that seeing an old friend causes pleasure? And should we assume that pleasure, in turn, causes an action like embracing? Or should a different causal role be assigned to pleasure?

Philosophers in the later Middle Ages tried to answer all of these questions by providing both a structural and a functional analysis of emotions or, more precisely, of "passions of the soul" (passiones animae), as they used to call the mental phenomena a person experiences or "undergoes" when she is in an affective state. ${ }^{1}$ Since most fourteenth-century authors worked with an Aristotelian theory of the soul, they examined two levels when analyzing passions. ${ }^{2}$ First, they turned to the sensory soul, which

\section{Perler, Dominik:}

Emotions and Cognitions : Fourteenth-Century Discussions on the Passions of the Soul

Vivarium, Volume 43, Number 2, 2005, Seite 250-274

was divided into two parts: "cognitive" and "appetitive". They investigated the passions we find on this level and the causal role they play in our actions. Second, they examined the level

\footnotetext{
${ }^{1}$ For the technical use of the term "passio", rooted in Aristotelian metaphysics, see V. Hirvonen, Passions in William Ockham's Philosophical Psychology, Dordrecht 2004, 47-73.

${ }^{2}$ Ockham stresses that these two levels are really and not simply conceptually distinct; see Quodl. II, q. 10 (OTh IX, 156-161). All references to Ockham's works apply to the Opera Philosophica (= OPh) and Opera Theologica (= OTh), ed. by G. Gál et al., St. Bonaventure, N.Y., 1967-1988. On the metaphysical framework of his psychology, see M. McCord Adams, William Ockham, Notre Dame 1987, 654-664, and G. J. Etzkorn, Ockham's View of the Human Passions in the Light of his Philosophical Anthropology, in: W. Vossenkuhl and R. Schönberger (eds.), Die Gegenwart Ockhams, Weinheim 1990, 265-287.
} 
of the intellectual soul, which they also divided into a "cognitive" and an "appetitive" part, asking again what kind of passions are to be found there and how they differ from sensory passions. In their view, we are utterly unable to understand passions unless we analyze the relationship between cognitive and appetitive parts on each level as well as the interaction between the two levels. Only then do we get a clear picture of all the structural elements, and only then can we explain the causal role of all the relevant elements.

In light of this architecture of the soul, I intend to examine how two prominent fourteenth-century philosophers, William Ockham and his pupil Adam Wodeham, analyzed passions on both levels. It goes without saying that I will not be able to take into account all the dimensions of their complex explanatory model. I will discuss neither moral aspects (e.g., the importance attached to higher-level passions for the development of virtues) nor theological ones (e.g., the role passions play in the theory of beatific vision). ${ }^{3}$ Since I am primarily interested in structural and causal aspects, especially in the way later medieval philosophers related elements in the cognitive part of the soul to those in the appetitive part, I will focus on the interplay between these parts and on the impact it has for an explanation of human actions.

To avoid misunderstandings, I should point out that speaking about parts of the soul does not amount to introducing various homunculi or separate faculties. Ockham emphasizes that intellect and will are not different entities within the human soul. Ontologically speaking, they are one and the same substance that is capable of bringing about different states or acts. Thus, the intellect is nothing but the intellectual soul insofar as it produces cognitive acts, and the will is the very same soul insofar as it produces volitional acts. ${ }^{4}$ There is only a real distinction between intellectual and sensory soul, not between intellect and will. In giving such an ontologically parsimonious explanation, Ockham clearly uses his "cleaver" to cut away a multiplicity of entities and really distinct parts. $^{5}$

\section{Perler, Dominik:}

Emotions and Cognitions : Fourteenth-Century Discussions on the Passions of the Soul Vivarium, Volume 43, Number 2, 2005, Seite 250-274

It is therefore hardly adequate to investigate the relationship between various parts understood as special entities, even if ones uses the expressions "intellect" and "will", as Ockham (and following him Wodeham) himself does. The basic questions should rather be how intellectual

\footnotetext{
${ }^{3}$ For a comprehensive account of both moral and theological aspects, see S. Knuuttila, Emotions in Ancient and Medieval Philosophy, Oxford 2004, ch. 4.

${ }^{4}$ See Reportatio II, q. 20 (OTh V, 435-436).

5 On this methodological principle, see J. Boler, Ockham's Cleaver, in: Franciscan Studies, 45 (1985), $119-144$
} 
and volitional acts are interrelated and how they are based upon acts brought about by the sensory soul.

\section{II}

If we want to understand the activities of the sensory soul, we need to look at the way Ockham explains sensory cognition (notitia sensitiva). In his view, this type of cognition provides information about particular, material things and can be either intuitive or abstractive, depending on the senses that are involved. ${ }^{6}$ If the external senses are activated, and if they grasp something present to them as present and existent, an intuitive cognition occurs. If, however, only the imagination as an internal sense is active and apprehends a thing without taking notice of its existence, there is mere abstractive cognition. This distinction can be illustrated with a simple example. Suppose there is an apple in front of you and you see it as an existent apple. In that case, you have a sensory intuitive cognition. If there is no apple physically present to you, but you are terribly hungry and visualize an apple in your imagination, then you have nothing more than a sensory abstractive cognition. Normally, such an abstractive cognition presupposes an earlier intuitive one, for you cannot visualize an apple if you have not already seen one.

So far, the intellect has not been involved in the cognitive process. There is intellectual cognition (notitia intellectiva) only when the intellect starts forming mental terms, i.e., concepts, and when it apprehends the object by means of these terms. ${ }^{7}$ Here, Ockham again distinguishes between intuitive and abstractive cognition. ${ }^{8}$ Intuitive cognition occurs when the

\section{Perler, Dominik:
Emotions and Cognitions : Fourteenth-Century Discussions on the Passions of the Soul Vivarium, Volume 43, Number 2, 2005, Seite 250-274} S. 254

intellect apprehends a present and existent thing as an existent thing. More precisely, Ockham claims that by means of this cognition "one can know whether or not there is a thing such that, if there is a thing, the intellect immediately judges that it is and knows with evidence that

\footnotetext{
${ }^{6}$ See Reportatio II, q. 12-13 (OTh V, 256-261); Reportatio III, q. 3 (OTh VI, 114-125). The thesis that sensory intuitive cognition provides the basis for further cognition is already stated in Ordinatio I, prologus (OTh I, 25).

${ }^{7}$ On Ockham's identification of concepts with mental terms, thoroughly discussed by recent commentators, see C. Panaccio, Les mots, les concepts et les choses. La sémantique de Guillaume d'Occam et le nominalisme d'aujourd'hui, Montréal-Paris 1991, and D. Perler, Theorien der Intentionalität im Mittelalter, Frankfurt a. M. 2002, 361-385.

${ }^{8}$ See Ordinatio I, prologus (OTh I, 30-33) and Quodl. V, q. 5 (OTh IX, 495-500). On this distinction, widely discussed in recent secondary literature, see the concise analysis provided by C. Michon, Nominalisme. La théorie de la signification d'Occam, Paris 1994, 108-126, and E. Karger, Ockham's Misunderstood Theory of Intuitive and Abstractive Cognition, in: P. V. Spade (ed.), The Cambridge Companion to Ockham, CambridgeNew York 1999, 204-226.
} 
it is." $"$ Thus, an intuitive intellectual cognition is always followed by a judgment about the existence or non-existence of the cognitive object. Abstractive intellectual cognition, on the other hand, is not followed by such a judgment. In that case, the intellect "abstracts from the existence or non-existence and from other conditions which contingently apply to a thing or are predicated of a thing." $" 10$ This means that if I simply conceive of an apple, I do not judge about the actual existence of an apple. I merely grasp a certain cognitive content.

This distinction between sensory and intellectual cognition is crucially important for an understanding of the passions, because Ockham emphasizes that it is sensory cognition, not the external object or intellectual cognition of this object, that immediately causes passions such as pleasure, desire, and sadness. ${ }^{11}$ Thus, when I meet an old friend, it is not the friend herself or my thinking about her, but my seeing her that causes pleasure in me. Before I activate my intellect and, accordingly, before I form or use any concepts, my seeing immediately triggers a passion. ${ }^{12}$ Of course, Ockham acknowledges that in most cases sense and intellect cooperate so that the intellect works upon the material provided by the senses and comes up with an intellectual cognition. But he insists on the fact that sensory cognition is not necessarily followed by, or transformed into, an intellectual one, as becomes clear when you consider infants who do

\section{Perler, Dominik:}

S. 255

Emotions and Cognitions : Fourteenth-Century Discussions on the Passions of the Soul

Vivarium, Volume 43, Number 2, 2005, Seite 250-274

not yet use concepts but nevertheless have sensory cognitions causing passions (e.g., seeing the mother or tasting milk causes pleasure). ${ }^{13}$ It is even more obvious in the case of brute animals. Ockham mentions the famous case of the sheep that flees when seeing a wolf. ${ }^{14}$ The mere act of seeing terrifies the sheep and makes it flee. Thus, there can be a sensory cognition causing a passion without the presence of any intellectual activity.

\footnotetext{
${ }^{9}$ Ordinatio I, prologus (OTh I, 31): “... notitia intuitiva rei est talis notitia virtute cuius potest sciri utrum res sit vel non, ita quod si res sit, statim intellectus iudicat eam esse et evidenter cognoscit eam esse..."

${ }^{10}$ Ordinatio I, prologus (OTh I, 31): "Aliter accipitur cognitio abstractiva secundum quod abstrahit ab exsistentia et non exsistentia et ab aliis condicionibus quae contingenter accidunt rei vel praedicantur de re."

${ }^{11}$ See Quaestiones variae, q. 6, art. 9 (OTh VIII, 251); Quodl. III, q. 17 (OTh IX, 268-272); Ordinatio I, dist. 1, q. 3 (OTh I, 420).

${ }^{12}$ Ockham makes it clear that the external object cannot be more than a mediate cause. Quaestiones variae, q. 6, art. 9 (OTh VIII, 252): "Et per consequens obiectum apprehensum nullo modo est causa immediata istarum passionum. Sed solum si sit causa [...], est solum causa mediata respectu illius passionis et solum causa causae quatenus naturaliter causat cognitionem intuitivam in sensu et eam conservat, quae cognitio causat immediate passiones praedictas modo praedicto.”

${ }^{13}$ Infants are mentioned in Reportatio IV, q. 14 (OTh VII, 314), and in Quodl. I, q. 15 (OTh IX, 84), where Ockham states: "puer videt sensibiliter et non intellectualiter...". He even assumes that they have some form of non-intellectual judgment. They judge that something is agreeable or disagreeable without using the concepts "agreeable" and "disagreeable".

${ }^{14}$ See Ordinatio I, dist. 3, q. 2 (OTh II, 410-411).
} 
This claim inevitably raises the question of how we should understand this type of cognition. What exactly does it mean that we (as well as brute animals) can see something without making use of concepts? Unfortunately, Ockham does not give a detailed answer to this question. Modern readers may immediately raise the objection that it hardly makes sense to speak about pre-conceptual seeing. ${ }^{15}$ If seeing is more than the mere reception of sensory inputs, it always involves an explicit or implicit use of concepts: we always see something as something and thereby categorize the perceptual object. For instance, you see the red, round thing in front of you as an apple or simply as a red, round thing. That is why you make use of concepts in the very act of seeing and not in a later act of intellectual apprehension. So, Ockham's claim that there are pre-conceptual sensory acts of cognition causing passions before the intellect provides concepts looks questionable.

Although it is tempting to argue in this way, I do not think that Ockham's claim should be dismissed so easily. Let me try to explain this by probing the examples he discusses. The most illuminating cases are those of animals that have mere sensory cognition. ${ }^{16}$ When a sheep sees a wolf, it apprehends the so-called "external sensible qualities" of the wolf, i.e., its color, its shape, its size, etc., and it immediately cognizes that a thing having all these properties is dangerous. Ockham emphasizes that the sheep does not apprehend the concepts of color, shape, etc. It simply perceives some patches that happen to have a certain color, shape, etc. Nor does it grasp dangerousness or hostility as a special quality

\section{S. 256 \\ Emotions and Cognitions : Fourteenth-Century Discussions on the Passions of the Soul Vivarium, Volume 43, Number 2, 2005, Seite 250-274}

that would be added to the sensible qualities. Criticizing some of his predecessors, among them Thomas Aquinas, Ockham holds that there is no special intentio, as claimed by these authors ${ }^{17}$ that could be grasped. Dangerousness is simply what results from a thing displaying certain qualities. That is why the sheep grasps the sensible qualities of the wolf and its property of being dangerous at the same time. In addition, the sheep is also capable of distinguishing the wolf from other things displaying other sensible qualities. Ockham even claims that the sheep is capable of making some kind of judgment, although he hastens to add that it does not form a full-fledged judgment that would involve the use of concepts. The sensory judgment is a mere act of recognizing and locating a certain pattern of sensible qualities. When performing this act, the sheep sees the wolf as something, in the sense that it sees it as a specific bun-

\footnotetext{
${ }^{15}$ In the current debate, J. McDowell, Mind and World, Cambridge, Mass., 1994, 46-65, takes this line in his critique of theories of pre-conceptual perception.

${ }^{16}$ See Reportatio IV, q. 14 (OTh VII, 314-315), and Ordinatio I, dist. 3, q. 2 (OTh II, 410-411).

${ }^{17}$ See Thomas Aquinas, Summa theologiae, ed. by P. Caramello, Turin-Rome 1952, pars I, q. 78, art. 4, corp.
} 
dle of colors, and it is capable of discriminating this bundle from another one, say from the one it sees when looking at a fellow sheep. Yet it is utterly unable to see the wolf as a wolf, simply because it cannot apply an appropriate concept to what it sees.

In light of the specific capacity that an animal with mere sensory cognition has, we can conclude that this type of cognition is indeed pre-conceptual, but nevertheless more than the reception of an unstructured stream of sensory inputs. It has a distinct content that enables an animal to distinguish different things in the material world. This is important for an understanding of the genesis of sensory passions, for it is precisely the sensory cognition having a distinct content that causes them. Ockham says with respect to the fleeing sheep: "Then I ask: what could cause this act of desiring to flee? Not the hostility, for there is no such thing there, and what does not exist cannot be a cause of anything. Therefore, this act is caused by a cognition of the external sensible qualities..."18 So it is the act of seeing, not the thing itself or a mysterious entity called "hostility", that causes a passion. This occurs naturally, without any intellectual intervention. Ockham acknowledges that not only animals experience such passions. Human beings have them as well. That is why he claims that human pleasure and desire are often naturally caused by sensory

\section{Perler, Dominik:}

S. 257

Emotions and Cognitions : Fourteenth-Century Discussions on the Passions of the Soul

Vivarium, Volume 43, Number 2, 2005, Seite 250-274

cognitions, without there being any use of concepts. To illustrate this point with a modern example, we may say: when I see and smell a bouquet of fresh flowers, it is not the use of the concepts "flowers" and "fresh" and, hence, not the conceptualization of the present situation that makes me feel pleasure. Rather, the simple fact that I experience enjoyable sensible qualities causes my pleasure.

This has a consequence for an explanation of how passions can be controlled or corrected. Do I have direct control over my pleasure when I see and smell fresh flowers? Hardly, Ockham would respond. The flowers naturally cause a certain type of sensory cognition in me, which in turn naturally causes pleasure. I cannot dictate to my senses not to provide a certain visual and olfactory cognition, and not to cause pleasure. Similarly, the sheep cannot decide not to be terrified when it sees the wolf. The passion arises naturally. However, this does not mean that we have no control whatsoever over our sensory passions. Ockham carefully points out that human beings, unlike brute animals, can exercise a certain control over them, because they are capable of bringing about acts of the will. But these acts cannot direct-

${ }^{18}$ Ordinatio I, dist. 3, q. 2 (OTh II, 411): "Tunc quaero: a quo causaretur ille actus appetitivus fugiendi? Non ab inimicitia, quia nulla est ibi, et non-ens nullius potest esse causa; igitur causatur a cognitione sensibilium exteriorum...” 
ly change or influence passions. They are only capable of producing a certain disposition that influences the way we see things. "Or," Ockham continues, "perhaps the act of the will is a mediate cause with respect to these passions, because it is the cause of the cause. For it is the partial immediate cause of an apprehension that precedes such an act called 'passion'."19 This claim can easily be illustrated. Suppose that I decide to go to a flower shop where I will be exposed to exquisite scents and colors. In that case, my decision (an act of the will) is a mediate cause of pleasure, because it makes me go to a place where I will acquire a certain sensory cognition. This cognition will then cause pleasure. But the act of the will can by no means function as the immediate cause of pleasure. Were I exposed to rotten flowers, I could not command myself: feel pleasure! No matter how much I want a sensory passion, I cannot have it unless I have previously had the necessary sensory cognition. ${ }^{20}$

The fact that acts of the will can be an indirect cause shows that there is an important difference between human beings and brute animals.

\section{Perler, Dominik:
Emotions and Cognitions : Fourteenth-Century Discussions on the Passions of the Soul Vivarium, Volume 43, Number 2, 2005, Seite 250-274}

When a sheep sees a wolf, it cannot want to avoid the passion of fear, simply because it lacks volitional acts. It cannot even want to be in a situation where it would not be scared. We human beings, on the other hand, can want to expose ourselves to situations where we have different sensory cognitions and, consequently, different passions. In addition, we can use our intellect in order to conceive of one and the same situation in different ways. Suppose you suffer from wolf-phobia just like a sheep, but you learn that there are nice, tame wolves in the circus. Then, you can want to go to the circus so that you will have a sensory cognition of a wolf that will be shaped by what you have learned. That is, you will no longer see the wolf as a mere bundle of sensible qualities that scares you. You will see it as a tamed animal. This may make you overcome your wolf-phobia. So, unlike the unfortunate sheep, you can do something to change your passions. This is an important point in Ockham's theory. While not being under the immediate control of acts of the will, passions are not out of control either. We can force ourselves to an éducation sentimentale (a) by exposing ourselves to situations in which we acquire certain sensory cognitions and (b) by conceptualizing these basic cognitions.

${ }^{19}$ Reportatio III, q. 12 (OTh VI, 411): "Vel forte ipse actus voluntatis est causa mediata respectu illarum passionum, quia est causa causae. Est enim causa immediata partialis apprehensionis praecedentis talem actum qui vocatur passio."

${ }^{20}$ Note that this cognition does not need to be directly caused by an external object. Since it can also be abstractive, i.e., an act of imagination, it can be caused by the sensory soul itself. For example, I can force myself to come up with an imagination of a delicious apple, which will cause pleasure. 
At this point someone might voice a fundamental objection against Ockham's claim that sensory cognitions cause passions. Why does he not admit that objects in the world play this causal role? Could he not appeal to his famous ontological razor or "cleaver" and claim that the wolf immediately causes fear when it is present to a person or to a sheep? No doubt, Ockham would reject this suggestion because it misses the crucial point that an object in itself simply triggers our senses - nothing more. In some passages, he presents an explicit argument endorsing the thesis that it is the sensory cognition, not the external object, that plays the causal role. ${ }^{21}$ If the object caused a passion, he says, the passion would disappear as soon as the object would be removed or destroyed. However, it is possible for a passion to persist after the removal or destruction of the object. (Suppose you see a wild wolf in the dark and are terribly scared. Then the wolf disappears. Yet you are still shaken by fear because you still have the strong impression of something big, dark, and threatening.

\section{Emotions and Cognitions : Fourteenth-Century Discussions on the Passions of the Soul Vivarium, Volume 43, Number 2, 2005, Seite 250-274}

It is the persisting content of your previous act of seeing that maintains your fear.) Ockham even adduces an argument ex hypothesi to corroborate this claim: "If God preserved the seeing of a pleasurable or saddening object and destroyed the object of that act of seeing, the pleasure or sadness in the appetite following the sense of sight could nevertheless be caused, as is clear from experience." 22 Appealing to experience may be difficult in this case, but the crucial point is clear. A passion can be caused even without the presence of an external object; therefore, the external object cannot be the immediate cause of a passion. This is an important thesis that should not be neglected. In Ockham's view, passions should not be explained in a crude behaviorist way, because it is not simply the stimulus stemming from an external object that causes a passion as a reaction. Rather, our sensory cognition plays the decisive causal role. To put it in a nutshell, we may say that it is not the world itself, but our sensory cognitive attitude toward the world that causes passions. This is why passions are "cognitively penetrable", as modern psychologists and philosophers of mind would say. ${ }^{23}$ Shifts in the way we cognize the world immediately affect our passions.

Now one may still wonder in what sense passions are "cognitively penetrable". Does that mean that we first need to have a sensory cognition so that we can acquire a passion that, taken in itself, is a mere sensation? Or does it mean that we need to have a sensory cognition

${ }^{21}$ See Quaestiones variae, q. 6, art. 9 (OTh VIII, 251-252); Quodl. III, q. 17 (OTh IX, 268-269).

${ }^{22}$ Quaestiones variae, q. 6, art. 9 (OTh VIII, 251-252): "Si etiam Deus conservaret visionem alicuius obiecti delectabilis vel tristabilis et destrueret obiectum illius visionis, potest statim causari delectatio vel tristitia in appetitu sequente visum, sicut patet per experientiam."

${ }^{23}$ I borrow this expression from Z. Pylyshyn, Computation and Cognition, Cambridge, Mass. 1984. 
so that we can acquire a passion that has in itself a cognitive content? This question arises because in his discussion of sensory passions, Ockham mentions not just pleasure and desire, but also pain. ${ }^{24}$ Yet pain seems to be a state without a cognitive content. Using modern terminology, one could say that pain has a certain phenomenal quality (it feels a certain way to have, say, a headache), but not a cognitive content (a headache is not about something and does not represent a certain object or quality in the world). ${ }^{25}$ If Ockham treats pain along with other sensory passions, it seems

\section{Emotions and Cognitions : Fourteenth-Century Discussions on the Passions of the Soul Vivarium, Volume 43, Number 2, 2005, Seite 250-274}

as if he were reducing all passions to mere sensations that lack a cognitive content.

Tempting as this interpretation may be, it would not be a correct account of Ockham's theory. In his explanation of various sensory passions, he makes it clear that most of them are about something, and therefore have a cognitive content. He states, for instance, that pleasure is about something present, whereas desire and avoidance are about some thing that is not present and not possessed. ${ }^{26}$ This clearly shows that he takes these passions to be intentional states: they are directed toward present or non-present objects. Even pain is intentional in his view. ${ }^{27}$ Or to be more precise, pain as a passionate attitude towards something bad that affects the body is intentional. Ockham carefully distinguishes pain, understood in this sense, from pain understood as a mere feeling. ${ }^{28}$ Therefore, it would be erroneous to say that Ockham considers passions to be non-intentional sensations or moods. Most of them are fully cognitive: not only are they caused by sensory cognitions, they also have a cognitive content in themselves.

\section{III}

Sensory cognition is the starting point for every cognitive activity and the first cause of passions. Yet it is clear that human beings also have an intellectual soul, which, just like the sensory soul, can bring about cognitive acts (so-called "intellectual acts") and appetitive acts (so-

\footnotetext{
${ }^{24}$ Pain is the passion he discusses most extensively in Quodl. III, q. 17 (OTh IX, 269-270).

${ }^{25}$ This is, of course, a controversial claim that would not be unanimously accepted in the contemporary debate. It is usually discussed as "the phenomenological theory", for instance by P. Smith and O. R. Jones, The Philosophy of Mind. An Introduction, Cambridge-New York 1986, 193-206.

${ }^{26}$ Quaestiones variae, q. 6, art. 9 (OTh VIII, 256). Ibid. (OTh VIII, 252), he says that desire and avoidance are "respectu obiectorum absentium et non habitorum".

${ }^{27}$ Quodl. III, q. 17 (OTh IX, 271): “... quando est delectatio vel dolor de aliquo obiecto, cessat actus desiderandi." Ockham explains the transition from one passion to another by referring to the object of the passion. If the object of desire, which has not been present, suddenly becomes present, desire ceases and is replaced by pleasure (if the object is good) or pain (if the object is bad). This explanation shows that passions are defined with respect to a certain object.

${ }^{28}$ See Quodl. III, q. 17 (OTh IX, 269).
} 
called "volitional acts"). This is precisely what distinguishes human beings from brute animals, which are only endowed with a sensory soul. Since human beings can have higher-level acts, Ockham introduces "passions of the will" that play a decisive role in his theory of emotions. ${ }^{29}$ His most extensive discussion

\section{Perler, Dominik:}

Emotions and Cognitions : Fourteenth-Century Discussions on the Passions of the Soul Vivarium, Volume 43, Number 2, 2005, Seite 250-274

of these passions can be found in a context that may look strange to modern readers, but was of great importance in the later Middle Ages, namely the debate about enjoyment (fruitio). According to traditional Christian doctrine, God is the highest and final object - the only object human beings enjoy for its own sake, not with regard to something else. ${ }^{30}$ The most perfect enjoyment will be reached in the beatific vision, when human beings contemplate God in, and for, himself. This theological thesis immediately raises the philosophical question of what kind of emotional state enjoyment is. Given that the human soul, separated from the body, can have it, it is certainly not a sensory passion. And given that it is not implemented in the body, it does not bring about bodily actions. So, what is it, and how is it caused? These questions sparked a general discussion about the structure and the causes of non-sensory passions.

All philosophers and theologians involved in this debate agreed that enjoyment, unlike sensory pleasure, is a conceptualized form of passion. If someone enjoys God's presence, one loves him as God, categorizing him as the highest and most desirable being. Given this obvious fact, one may be tempted to say that enjoyment and other forms of higher-level passions are an intellectual affair. That is, the intellectual soul, by grasping an object and conceptualizing it, brings about all these passions in its cognitive activities.

\section{Perler, Dominik:}

S. 262

Emotions and Cognitions : Fourteenth-Century Discussions on the Passions of the Soul Vivarium, Volume 43, Number 2, 2005, Seite 250-274

\footnotetext{
${ }^{29}$ He explicitly speaks about passions, for instance in Quodl. II, q. 17 (OTh IX, 187): “... dico primo quod passiones sunt in voluntate, quia amor et spes, timor et gaudium sunt in voluntate, quae tamen communiter ponuntur passiones. Similiter delectatio et tristitia sunt in voluntate, quae etiam sunt passiones; igitur etc." Ockham was by no means the first medieval author to speak about passions of the will. He followed Scotus, who already presented a detailed analysis of these passions, and shifted the focus from the sensory to the volitional level. This crucial shift is analyzed by S. Knuuttila, Emotions in Ancient and Medieval Philosophy (n. 3), 265-271, and O. Boulnois, Duns Scot: Existe-t-il des passions de la volonté?, in: B. Besnier, P.-F. Moreau and L. Renault (eds.), Les passions antiques et médiévales, Paris 2003, 281-295. On the rise of voluntarist psychology in general, see B. Kent, Virtues of the Will. The Transformation of Ethics in the Late Thirteenth Century, Washington D.C. 1995.

${ }^{30}$ Peter Lombard states this thesis in the very first of his 48 distinctions, where he refers to the Augustinian distinction between enjoyment (fruitio) and use (usus): God is the only object enjoyed for its own sake, not used for something else. Given this classical distinction, all medieval theologians commenting on the Sentences dealt with the question of what kind of emotional state enjoyment is. On the theological background and its impact on philosophical debates, see A. S. McGrade, Ockham on Enjoyment - Towards an Understanding of Fourteenth Century Philosophy and Psychology, in: The Review of Metaphysics, 33 (1981), 706-728.
} 
Ockham firmly opposes such an intellectualist approach, holding instead that "enjoying is an act of the will alone." 31 He acknowledges that conceptualization plays a decisive role. But in his view, this does not amount to claiming that enjoyment is nothing but a special form of intellectual activity. Rather, it is the will that brings about an act of enjoyment when the intellect presents a certain object. Thus, when a person thinks about God, he or she performs an act of enjoyment that is a distinct volitional act. This separation of two acts seems to hint at a perfect analogy between "lower" and "higher" passions. As we have seen, on the sensory level, there needs to be a sensory cognition, which, however, is not in itself a passion. Rather, a sensory cognition causes a sensory passion. Similarly, one may say that on the higher level, there needs to be a conceptual cognition, which, taken in itself, is not yet a passion. Rather, a conceptual cognition causes a passion, i.e., a volitional act such as enjoyment.

Although it is tempting to construct such an analogy, it would not express Ockham's opinion. He explicitly rejects the claim that the intellect causes passions of the will, claiming instead: “... when the intellect presents an enjoyable object to the intellect - in a clear or in an obscure way, in particular or in general -, the will can actively produce an act of enjoyment with respect to that object, and this happens on natural grounds."32 Quite obviously, Ockham emphasizes that there is no simple causal mechanism that makes the will come up with a certain passion whenever the intellect delivers a particular cognition. ${ }^{33}$ The will can produce an act of enjoyment, but it need not.

Lurking in the background of this thesis is Ockham's famous doctrine of the liberty of the will: the will can act in conformity with objects and judgments presented by the intellect, but it does not have to. ${ }^{34}$ Even if

\section{Perler, Dominik:
Emotions and Cognitions : Fourteenth-Century Discussions on the Passions of the Soul Vivarium, Volume 43, Number 2, 2005, Seite 250-274}

the intellect conceives of an object as something good and desirable, the will is free not to accept it and, consequently, not to enjoy it. In fact, the will has three options: it can accept it, not accept it, or take a neutral stance. For that reason, enjoyment is not automatically caused

${ }^{31}$ Ordinatio I, dist. 1, q. 2 (OTh I, 395): “... primo ostendum est quod frui est actus solius voluntatis.”

32 Ordinatio I, dist. 1, q. 2 (OTh I, 397): “... dico primo quod obiecto fruibili ostenso voluntati per intellectum sive clare sive obscure sive in particulari sive in universali, potest voluntas active elicere actum fruitionis, et hoc ex puris naturalibus, circa illud obiectum."

${ }^{33}$ Ockham clearly rejects the thesis, defended by, among others, Aquinas (see his Scriptum super primum Sententiarum, ed. by P. Mandonnet, Paris 1929, dist. 1, q. 1., art. 1 ad 1), that the will always follows the intellect.

34 Ordinatio I, dist. 1, q. 2 (OTh I, 399): "Sed voluntas respectu cuiuscumque obiecti libere et contingenter agit, igitur simpliciter de potentia sua absoluta potest cessare ab actu suo." See also ibid., q. 6 (OTh I, 503); Reportatio III, q. 11 (OTh VI, 355); Reportatio IV, q. 16 (OTh VII, 350). For a concise analysis of the so-called liberty of indifference, see M. McCord Adams, Ockham on Will, Nature, and Morality, in: P. V. Spade (ed.), The Cambridge Companion to Ockham (n. 8), 245-272. 
by an intellectual apprehension. When such a passion arises, it requires its own cause: the will. $^{35}$

Now one might wonder how the structure of a volitional act of enjoyment is to be understood. Since Ockham often emphasizes that this act is distinct from an intellectual activity, it can hardly display the very same structure. Is it an act that has a mere phenomenal quality, comparable to a good feeling? Or is it an act that also comprises a cognitive component, even though it differs from an intellectual act? To answer these questions, we need to look at how Ockham explains the relationship between an act of enjoyment or a more mundane act of love (dilectio) and an act of pleasure (delectatio). Criticizing some of his contemporaries, among them Peter Auriol, he points out that there is a real distinction between these two acts. That is, a loving person who feels pleasure has two acts: (i) an intentional act of loving directed toward a certain person or state of affairs, and (ii) a non-intentional act of experiencing pleasure. The reason for this distinction is quite simple: there can be an act of love without there being an act of pleasure. ${ }^{36}$ Ockham adduces a colorful example to illustrate this thesis. A devil can love to seduce a human being and make him sin, but he does not experience any pleasure in this despicable deed. He has, as it were, a cool-hearted love. ${ }^{37}$ This example shows that an act of love is neither identical to, nor necessarily accompanied by, an act that has a certain phenomenal quality. It is not simply an act of "feeling good". Rather, an act of love (or in the case of love of God: an act of enjoyment) is an act that is about something and can be identified through its content. This content may be characterized in various ways, both as being propositional and non-propositional. Thus, the devil's act of love has the content that the human being should sin, whereas a human

\section{Perler, Dominik: \\ Emotions and Cognitions : Fourteenth-Century Discussions on the Passions of the Soul Vivarium, Volume 43, Number 2, 2005, Seite 250-274}

being's act of enjoyment simply has the content God. No matter how the content is structured (in a "complex" or a "simple" way, as Ockham would say), an act of love always has a content, and is therefore to be understood as a cognitive act. An act of pleasure, on the other hand, is a mere feeling that may or may not go along with the cognitive act.

${ }^{35}$ It should be noted that this appeal to a distinct cause does not involve an ontological commitment to a spooky entity called "the will". As pointed out above (see n. 5), Ockham does not introduce the will as an entity or faculty that would be really distinct from the intellect. The expression "the will" is always to be understood as "the intellectual soul insofar as it produces volitional acts". There is only an ontological commitment to various acts, not to various parts, of the soul.

${ }^{36}$ See Ordinatio I, dist. 1, q. 3 (OTh I, 407).

${ }^{37}$ See Ordinatio I, dist. 1, q. 3 (OTh I, 408). 
So far, it has become clear that volitional passions such as enjoyment and love are not only based upon cognitive acts, but are themselves intentional acts with a cognitive content. But how then can we distinguish them from simple intellectual acts? What, for instance, is the difference between the mere act of thinking about God and loving God, if it is not just a phenomenal quality that necessarily goes along with the second act and characterizes it? It looks as if the cognitive approach Ockham takes to the volitional passions risks assimilating them completely to intellectual acts.

In light of this difficulty, it is not surprising that Ockham's contemporaries and successors animatedly discussed the question of how we should characterize the structure of a volitional passion. Adam Wodeham, Ockham's pupil and secretary, deals with this problem in a very detailed study. ${ }^{38}$ Following his teacher, he subscribes to the thesis that enjoyment and love are acts of the will, which are not to be identified with or reduced to intellectual acts. He unmistakably rejects the intellectualist position, claiming that "the first cognition of an enjoyable object, be it an intuitive or an abstractive cognition, is really distinct from an enjoyment of that object, and vice versa, an enjoyment from this cognition." 39 Wodeham acknowledges, however, that intellectual acts are necessary for the genesis of passions. If someone had no idea whatsoever of God, they could clearly have no love of God. This fact shows that cognitions brought about by the intellect play the indispensable role of a partial cause. However, it by no means proves that they are the total or unique cause. ${ }^{40}$ In addition,

\section{Perler, Dominik:
Emotions and Cognitions : Fourteenth-Century Discussions on the Passions of the Soul Vivarium, Volume 43, Number 2, 2005, Seite 250-274}

Wodeham points out that "experience teaches that we frequently apprehend things which we neither hate nor love." ${ }^{41}$ This simple fact shows that an intellectual cognition does not automatically cause a passion: we can simply cognize God, or a fellow human or a material thing, without being compelled to have any passion. Nor is an intellectual cognition in itself a passion. Otherwise every person cognizing a certain object would inevitably be in a passionate

${ }^{38}$ Wodeham was by no means the only author to discuss this problem. Walter Chatton, Richard Fitzralph, Gregory of Rimini, Peter Ailly and others also analyzed it in detail. For an overview, see A. S. McGrade, Enjoyment at Oxford after Ockham: Philosophy, Psychology, and the Love of God, in: A. Hudson and M. Wilks (eds.), From Ockham to Wyclif, Oxford 1987, 63-88, and S. Knuuttila, Emotions in Ancient and Medieval Philosophy (n. 3), 275-282.

${ }^{39}$ Lectura secunda in librum primum Sententiarum, ed. by R. Wood, St. Bonaventure, N.Y., 1990, dist. 1, q. $5, \S 4$ (vol. I, 277): “... prima notitia fruibilis, sive intuitiva sive abstractiva, realiter distinguitur a fruitione eiusdem, et econtra ista fruitio ab illa cognitione."

${ }^{40}$ Wodeham argues that it is even excluded that they are the total cause, because nothing can fully cause itself, i.e., a cognition can not fully cause a cognitive passion. See Lectura secunda, dist. 1, q. 5, § 4 (vol. I, 277).

${ }^{41}$ Lectura secunda, dist. 1, q. 5, § 4 (vol. I, 278): "Item, experientia docet quod frequenter apprehendimus quae nec odimus nec diligimus." 
state. The wide diversity of human reactions toward one and the same object - some people feel love when cognizing a certain person, others do not - clearly shows that passions must not be identified with intellectual cognitions.

Now Wodeham faces a dilemma. On the one hand, he concedes that intellectual cognitions are the partial cause of passions, and that passions comprise a cognitive element because they are always about a certain object. On the other hand, he rejects an identification of passions with cognitions tout court. How are the two theses to be reconciled? Wodeham tries to find a solution by claiming that passions are indeed states with a cognitive content, but volitional states that are caused partially by cognitions of the intellect and partially by the will itself. That is why they are higher-level cognitions. In fact, Wodeham presents his second thesis as follows: "Second I say - not as the expression of an assertion but of an opinion - that every act of desiring and hating, and hence enjoyment, is some cognition and some apprehension, because every experience of an object is some cognition of that thing." ${ }^{, 42}$ Obviously, Wodeham defends a strong cognitivist position. Not only are passions of the will based upon (and partially caused by) a conceptualization of things, passions are a way of conceptualizing things. Therefore, it does not make sense to open a gap between the intellect that is responsible for concepts and the will that

\section{Perler, Dominik:}

Emotions and Cognitions : Fourteenth-Century Discussions on the Passions of the Soul Vivarium, Volume 43, Number 2, 2005, Seite 250-274

merely causes non-cognitive desires. Rather, the will is to be understood as a capacity that makes use of the concepts supplied by the intellect and produces conceptualized passions. Let me illustrate this important point with a modern example.

Suppose that you meet an old friend and are immediately filled with joy. In this case, you do not only have a sensory cognition (you see a familiar pattern of colors and smell a well-known scent) that makes you have the sensory passion of pleasure or "feeling good". You also recognize the person you meet as your friend and therefore conceptualize what you see and smell. This is what makes you feel joy. The important point is that in the very act of conceptualizing your friend as your friend you feel joy. Joy is not to be separated from this conceptual cognition. It is some form of cognition. Yet it is not a basic form of cognition. Otherwise, everyone conceptualizing your friend as, say, the neighbor living next door or a

${ }^{42}$ Lectura secunda, dist. 1, q. 5, § 4 (vol. I, 278): "Secundo dico - non asserendo sed opinandi - quod omnis actus appetendi et odiendi, et ita frui, est quaedam cognitio et quaedam apprehensio, quia omnis experientia alicuius obiecti est quaedam cognitio eiusdem." Although cautiously pointing out that he holds this position "opinandi", he presents it in detail and defends it against non-cognitivist accounts. Note that the "cognitio" Wodeham refers to is not a basic cognition. It is rather a cognition that presupposes a basic cognition supplied by the intellect. He makes this clear when saying in Lectura secunda, dist. 1, q. 5, § 6 (vol. I, 282): “... dico quod actus amandi naturaliter causatus requirit cognitionem praeviam quae non sit amor." 
six-foot tall person, would feel joy. You need to conceptualize your friend as your friend or as a good person in order to feel joy.

If we understand Wodeham's claim that every passion "is some cognition and some apprehension" in this way, it comes close to what is nowadays known as the cognitivist theory of emotions. But how then is the special way of cognizing to be understood? In the current debate, cognitivists give a clear answer to this question. M. Nussbaum, for instance, claims that emotions are "judgments of value," i.e., ways of evaluating things and states of affairs. ${ }^{43}$ Following this line, one might interpret Wodeham as claiming that passions of the will are a special kind of judgment - a judgment by which we evaluate things as good or bad for us.

Although Wodeham clearly defends a cognitivist position, we should be careful when appealing to judgments in a modern explanation of his view. If one takes a judgment to be something composed of the propositional attitude of affirming or denying and a propositional content ("I affirm/deny that p"), then Wodeham clearly denies that passions of the will are always judgments. In his third thesis, he unequivocally says that "a volition one has formed is an apprehending cognition, not an assenting one" 44 and argues for this claim as follows: “... something pleasurable can be loved if it is apprehended exclusively by a simple, non-complex

Perler, Dominik:
Emotions and Cognitions : Fourteenth-Century Discussions on the Passions of the Soul

S. 267

Vivarium, Volume 43, Number 2, 2005, Seite 250-274

cognition. And something can be loved when it is apprehended in a complex way, without there being any assent or dissent. Therefore, a volitional act is only an apprehension." 45 This sounds like puzzling scholastic jargon, but it makes perfect sense when we illustrate it with the example I just mentioned. When you meet an old friend, you can apprehend her as a friend or as a good person. This simple apprehension, which does not involve the objective judgment that she really is a good person (she might appear to be good just to you or just in a specific situation), suffices for a cognitive passion. You then love her as the person you apprehend under a certain aspect. And even if you apprehend your friend "in a complex way", i.e., by grasping a propositional content, all you need to apprehend is that she is a good person. In Wodeham's terminology, this propositional content is a "complexe significabile" that

${ }^{43}$ She calls her theory "the cognitive-evaluative view"; see M. C. Nussbaum, Upheavals of Thought. The Intelligence of Emotions, Cambridge-New York 2001, 23.

${ }^{44}$ Lectura secunda, dist. 1, q. 5, $\S 5$ (vol. I, 281): “... volitio aliqua creata est cognitio apprehensiva et non assensiva. Et haec potest esse tertia conclusio."

${ }^{45}$ Ibid.: "... aliquid delectabile potest diligi si apprehendatur tantummodo notitia simplici incomplexa, et aliquid potest diligi quando apprehenditur complexe absque omni assensu vel dissensu. Igitur aliqua volitio est apprehensio tantum." 
cannot be reduced to something non-complex. ${ }^{46}$ The important point is that you do not have to come up with the full-fledged judgment "I affirm that she is a good person" - grasping the propositional content suffices. For it is one thing to grasp such a content, quite another to give an assent or dissent to that content. ${ }^{47}$

Wodeham concedes that there may be judgments in some cases, and provides an illustrating example. ${ }^{48}$ If someone is happy about the death of his enemy, he does form a judgment in the very act of happiness, namely "The enemy is dead", which includes an assent to the fact that a certain person, apprehended as an enemy, is dead. It may be spelled out as follows: "I affirm that the person apprehended as an enemy is dead and I am happy about this fact." But the important point is that

\section{Perler, Dominik:}

Emotions and Cognitions : Fourteenth-Century Discussions on the Passions of the Soul Vivarium, Volume 43, Number 2, 2005, Seite 250-274

there does not need to be a judgment in every case of a cognitive passion. That is why Wodeham suggests that we should carefully distinguish between (a) cognitive passions that are mere apprehensions and (b) cognitive passions that involve judgments. This distinction has an important consequence for the problem of truth-values of passions, as Wodeham is quick to point out. ${ }^{49}$ If one has a passion of type (a), the content of the passion clearly does not have a truth-value. Thus, if you simply love your friend as a good person, the content as a good person is neither true nor false. If, however, someone judges that the enemy is dead and is happy about this fact, the content that the enemy is dead is true or false. It is precisely its truth-value that distinguishes such a propositional content from a non-propositional one.

The crucial point is that in every passion, whether it involves a judgment or not, an object or a state of affairs is apprehended in a certain way. This apprehension is not descriptive but evaluative, as Wodeham's own example of love makes clear. For even if the loving person does not form the judgment " $\mathrm{x}$ is a pleasurable thing", she apprehends $\mathrm{x}$ under a certain aspect, namely as something pleasurable (delectabile). In doing so, she clearly evaluates $\mathrm{x}$ as having a positive quality. This differs from a mere descriptive apprehension, an apprehension

\footnotetext{
${ }^{46}$ He presents his theory of the "complexe significabile" in Lectura secunda, dist. 1, q. 1, § 7-9 (vol. I, 192-197). For an analysis of this theory, see D. Perler, Late Medieval Ontologies of Facts, in: The Monist, 77 (1994), 149-169; E. Karger, William of Ockham, Walter Chatton and Adam Wodeham on the Objects of Knowledge and Belief, Vivarium, 33 (1995), 171-196; A. de Libera, La référence vide. Théories de la proposition, Paris 2002, 157-226.

${ }^{47}$ Note that this distinction is not identical with Seneca's famous opposition between the first and the second movement of an emotion; see De ira II, iv, 1, and the analysis provided by R. Sorabji, Emotion and Peace of Mind. From Stoic Agitation to Christian Temptation, Oxford 2000, 66-75. Seneca's first movement is involuntary and a mere "preparation for a passion", whereas Wodeham's apprehensive emotion is an act of the will and constitutes in itself a passion. The distinction between apprehensions and judgments is a distinction within the realm of volitional passions.

${ }^{48}$ This is his fourth thesis. See Lectura secunda, dist. 1, q. 5, § 5 (vol. I, 282).

${ }^{49}$ See Lectura secunda, dist. 1, q. 5, § 7 (vol. I, 284-285).
} 
of $\mathrm{x}$ as being tall or dark, for instance. This example shows that a cognitive passion, though not being an evaluative judgment in the strict sense, includes an evaluative element that distinguishes it from basic cognitions. This is one of the main reasons why a cognitive passion is a higher-level cognition. In having such a passion, one does not simply describe perceptible features of an object. One also evaluates the object as good or bad, agreeable or disagreeable.

In light of this distinction, we can draw a picture with the following hierarchy of cognitions: $:^{50}$

Perler, Dominik:

Emotions and Cognitions : Fourteenth-Century Discussions on the Passions of the Soul Vivarium, Volume 43, Number 2, 2005, Seite 250-274

sensory cognition: $\quad$ seeing or imagining $\mathrm{x}$ (pre-conceptual)

intellectual cognition: apprehending $\mathrm{x}$ as being $\mathrm{F}$ (conceptual and descriptive)

volitional cognition: (a) apprehending $\mathrm{x}$ as being good/bad (conceptual and evaluative)

(b) judging that $\mathrm{x}$ is $\mathrm{F}$ and taking this fact to be $\mathrm{good} / \mathrm{bad}$ (conceptual and evaluative)

To be sure, this appeal to different levels of cognition was by no means the standard approach chosen by all fourteenth-century authors. Gregory of Rimini and Peter of Ailly, for instance, rejected Wodeham's claim that there are various higher-level cognitions, some at the intellectual level and some at the volitional one. In particular, they criticized the thesis that passions of the will should be treated as forms of apprehension. ${ }^{51}$ Gregory tried to beat Wodeham with a typically Ockhamist weapon, namely by appealing to the principle of parsimony. He claimed: "He [Wodeham] superfluously posits a plurality of cognitions. He unnecessarily and superfluously posits something as a cognition." ${ }^{, 52}$ In Gregory's view, the will does not produce an additional cognition when it comes up with a passion like love or hate. The intellect

${ }^{50}$ This picture simply presents the hierarchical structure without taking into account all the possible interrelations between the various levels. Since human beings make simultaneous use of their sensory and intellectual capacities, activities on a higher level may very well shape those on a lower level. For instance, the way we conceive of and categorize objects has an impact on the way we see and imagine them. For that reason, there are not only preconceptual acts of seeing and imagining on the first level (as in the case of brute animals), but also conceptualized ones. Following Aristotle (see An. Post. II, 19; 100b1), all medieval authors conceded that we do not simply see or apprehend individual items, but also universals (e.g., we see Callias as a man). This clearly presupposes the use of concepts in the very act of seeing.

${ }^{51}$ See Gregory of Rimini, Lectura super primum et secundum Sententiarum. Tomus I: super primum prologus et dist. 1-6, ed. by D. Trapp and V. Marcolino, Berlin-New York 1981, dist. 1, q. 1, 212-217; Peter of Ailly, Tractatus de anima, edited in: O. Pluta, Die philosophische Psychologie des Peter von Ailly, Amsterdam 1986, 83-84.

${ }^{52}$ Gregory of Rimini, Lectura super primum et secundum Sententiarum, dist. 1, q. 1 (ed. Trapp and Marcolino, 212): “... superflue ponit pluralitatem notitiarum et inutiliter seu superflue ponit aliquam rem esse notitiam." 
already provides a full cognition, both descriptive and evaluative, while the will simply adds an affective component.

This reaction to Wodeham's analysis shows that the cognitivist account of passions sparked a heated debate about the structure of emotions. This debate focused on the fundamental question of how passions can acquire a cognitive element that goes beyond a mere descriptive account of a thing or a state of affairs. Whereas Wodeham tried to locate this element in a specific evaluation, others denied that the will is responsible for such an element. Consequently, they rejected the postulation of higher-level cognitions.

Yet Gregory of Rimini's claim that the will does not add a cognitive element but simply an affective one, raises an important question. Is there any place for an affective component in Wodeham's theory? It looks as

Perler, Dominik:
Emotions and Cognitions : Fourteenth-Century Discussions on the Passions of the Soul

Vivarium, Volume 43, Number 2, 2005, Seite 250-274

if he were presenting an analysis of emotions that identifies them with "cool-hearted" higherlevel cognitions. For instance, loving someone seems to amount to coming up with an evaluation of that person as being good. But what about the aspect of desperately longing for this person or feeling good when being with her? Are these non-evaluative elements missing in Wodeham's theory? Not quite so. In his analysis of enjoyment, Wodeham emphasizes that "beatific enjoyment is really pleasure." ${ }^{53}$ Unlike Ockham, he does not separate pleasure (delectatio) from love (dilectio). These are not two distinct states that can but need not co-exist. In Wodeham's view, love or enjoyment always includes pleasure because enjoyment is a state "by which misery is formally excluded". 54 Therefore, it hardly makes sense to say that the devil enjoys deceiving human beings but feels miserable about it. If he really experiences enjoyment, the feeling of pleasure necessarily goes along with it. (Of course, the devil may have another kind of emotion that includes the element of feeling miserable. But this emotion would not be plain enjoyment but, say, sadistic joy.) The fact that Wodeham explicitly includes an affective component in the emotion and even considers it to be a defining feature of that emotion, shows that he does not adopt a purely rationalist explanation of emotions that ignores all non-cognitive elements. Rather, he offers a sophisticated explanation, taking into account both a cognitive component (an evaluative apprehension or a judgment) and an affective component. In fact, it is the presence of both components that characterizes a full-fledged

${ }^{53}$ Lectura secunda, dist. 1, q. 6, § 2 (vol. I, 295): “... teneo primo illam conclusionem quod fruitio beatifica est realiter delectatio."

${ }^{54}$ Lectura secunda, dist. 1, q. 6, § 2 (vol. I, 295): “... sola illa est fruitio beatifica per quam formaliter excluditur miseria, sic scilicet quod sibi formaliter repugnet miseria." 
emotion like love or enjoyment. For it is neither a "cool-hearted" evaluation of a state of affairs nor a simple feeling, but an evaluation that includes a certain feeling.

V

I hope my reconstruction of Ockham's and Wodeham's account of the passions makes clear that these philosophers took passions to be thoroughly "cognitively penetrated", both on the sensory and on the intellectual level. In their view, passions are not mental states that are somehow opposed to, or isolated from, cognitions. Quite to the contrary, neither the genesis

Perler, Dominik:
Emotions and Cognitions : Fourteenth-Century Discussions on the Passions of the Soul

S. 271

Vivarium, Volume 43, Number 2, 2005, Seite 250-274

of passions, nor their internal structure, can be explained without an appeal to cognitive activities. This has an immediate consequence for an understanding of the relationship between the so-called "cognitive" and the "appetitive" part of the soul. When Ockham and Wodeham referred to these parts, they did not intend to divide the soul into two neatly separated sections. Nor did they want to introduce various homunculi that would somehow be hidden but nevertheless active in a human being. Rather, their intention was to refer to mental activities that a person performs when he or she copes with complex situations. It is in fact the coordination of various mental activities that distinguishes a person from a brute animal, on the one hand, and from an angel, on the other. For an animal, endowed with a sensory soul, is capable of having mere sensory passions that enable it to behave in an appropriate way. But it is utterly unable to conceptualize the situation with which it is confronted. Consequently, it cannot have higher-level passions by which it would evaluate or assess a given situation. Nor can it try to conceptualize the situation in various ways, so that it would come up with different passions. It is a helpless victim of its naturally caused passions. Angels, on the other hand, endowed with an intellectual soul, are clearly capable of forming intellectual and volitional acts, and are therefore able to develop a conceptualized passionate attitude towards things with which they are confronted. ${ }^{55}$ Yet angels lack sensory cognition and therefore cannot have bodily passions that would make them cry or laugh. As fleshless beings, they are condemned to have fleshless passions. Occupying a middle position between animals and angels, human beings have both a sensory and an intellectual soul. This allows them to bring about lowerand higher-level passions, i.e., embodied and conceptualized emotions. In fact, it was this middle position on which Ockham, Wodeham, and many other medieval philosophers were focusing when they tried to explain human passions. This enabled them to avoid reducing a

${ }^{55}$ Ockham discusses angelic passions (his main example is love) in Quaestiones variae, q. 6, art. 9 (OTh VIII, 257-258 and 269-270). 
human being to a mere bodily creature, condemned to have naturally caused sensory passions, or to some kind of free-floating soul, limited to immaterial passions.

At this point, someone working on contemporary theories of emotions and influenced by neurobiological research may raise a serious objection. If Ockham and Wodeham were indeed concerned with the interplay between various mental activities, and if they located some of them in

Perler, Dominik:
$\begin{aligned} & \text { Emotions and Cognitions : Fourteenth-Century Discussions on the Passions of the Soul } \\ & \text { Vivarium, Volume 43, Number 2, 2005, Seite 250-274 }\end{aligned}$

S. 272

the body, why did they not analyze their material implementation? Why did they not look at how they are present in the brain? Should an adequate theory not give a detailed explanation of the neurobiological processes that are necessary for the rise of passions?

In response to this objection, one could point out that Ockham and Wodeham, like the majority of later medieval thinkers, certainly did not locate all mental activities in the body. Since they took the intellectual soul to be an entity that is not subject to material conditions, they would have denied that there could be a neurobiological explanation (or in medieval terms: an explanation within the framework of the physica) of all the passions. They were quite obviously only "semi-materialists" in their metaphysics of the soul. ${ }^{56}$ But even on the level of the sensory soul and its activities, which clearly are subject to material conditions, Ockham and Wodeham did not attempt to provide a biological or a physical analysis, as some of his contemporaries (e.g. the members of the medical school of Padova) did - for good reason. For, if one deals with passions, one should carefully distinguish between a philosophical and a scientific enterprise. In a scientific investigation, one does indeed look at the material implementation of passions and at the biological processes that are required for such an implementation. In the fourteenth century, such an investigation would have concentrated on the arrangement of so-called "ventricles" in the brain. In a philosophical investigation, however, one ought to look at the different elements that play a role in the genesis of passions and at the functional mechanisms, which may be biologically instantiated in one way or another. Such a functional explanation must not be conflated with a material one, for even if one has perfect knowledge of the somatic basis, one still ought to explain what happens on this basis. And it may well be, as modern functionalists are keen to point out, that a certain type of passion can have different material instantiations in different human beings. Therefore, Ockham's and Wodeham's functional explanation is not as incomplete as it may look at a first glance. It is an explanation that appeals (a) to functional elements provided by the various mental activities,

${ }^{56}$ I borrow this expression from R. Pasnau, Theories of Cognition in the Later Middle Ages, CambridgeNew York 1997, 36. 
and (b) to functional mechanisms that relate these elements to each other. This type of explanation may help shed light on the problem of

\section{Perler, Dominik:}

S. 273

Emotions and Cognitions : Fourteenth-Century Discussions on the Passions of the Soul

Vivarium, Volume 43, Number 2, 2005, Seite 250-274

emotional conflict, probably one of the most bewildering problems we are confronted with when trying to cope with emotions. Let me highlight this advantage by returning to the example I mentioned at the very beginning of this paper.

I asked you to imagine the case of a friend who had left you without any explanation and reappeared after a couple of years. When she shows up, you are likely to react with mixed emotions: you are pleased, angry, and you may also feel guilty. How is this possible? How can you have both positive and negative emotions? Using Ockham's and Wodeham's functional model, one could give the following explanation. The sensory cognition you have when seeing your friend immediately causes the sensory passion of pleasure, a passion that arises naturally. Yet at the same time, your intellect conceives of your friend as someone who had left you without any warning. This triggers your will, which evaluates the friend as an unreliable, or even a betraying, person and brings about the passion of anger. Your intellect also conceives of yourself as a person who did not try to remain in contact with your friend. This makes your will evaluate yourself as an unreliable or betraying person as well; consequently, you feel guilty. Given the simultaneous presence of all these acts, you have all three passions at once. And you are in an emotional conflict because the three passions, based on different cognitions and evaluations, oppose each other.

It was this possibility of conflict that late medieval philosophers wanted to point out in their functional explanation: different cognitions play different causal roles in the mechanism of the mind, and consequently, they give rise to different passions. Their intention was not simply to dissolve emotional conflict by claiming that, say, the will as a higher faculty perfectly controls all the passions and unifies them. They admitted, of course, that the will has a certain ruling power, and in their theories of virtues, they assigned to it the task of bringing about the best possible higher-level passions, which would become some kind of second nature and influence the genesis of our sensory passions. Yet they insisted on the fact that the so-called lower-level passions should not be neglected. The will is not a magic power that could, or should, make the sensory passions disappear. Nor can it arrange all the higher-level passions in a harmonious way. It is just one capacity of the soul that cooperates with other capacities to bring about a multitude of passions - passions that may be in conflict with each other. One can do justice to the 
Emotions and Cognitions : Fourteenth-Century Discussions on the Passions of the Soul

Vivarium, Volume 43, Number 2, 2005, Seite 250-274

complex emotional life of a person only if one acknowledges the possibility of such a conflict and if one tries to analyze the elements that play a role in this conflict. ${ }^{57}$

\section{Berlin}

Humboldt-Universität

${ }^{57}$ Earlier versions of this paper were presented at the Universite de Montréal, Saint Louis University, and Washington University. I am grateful to the audience in all three places for stimulating questions and critical remarks. 